\title{
PENYELESAIAN PERJANJIAN KREDIT TERHADAP DEBITUR YANG WANPRESTASI DI PT. BANK PERKREDITAN RAKYAT HARI DEPAN DENPASAR
}

\author{
Ni Made Lady Ruslya, I Nyoman Putu Budiartha, Ida Ayu Putu Widiati \\ Fakultas Hukum Universitas Warmadewa, Denpasar-Bali, Indonesia \\ Ladyruslya22@gmail.com, budiartha.fhwjurnal@gmail.com, idaayuwidiati.fhwjurnal@gmail.com
}

\begin{abstract}
Abstrak
Indonesia merupakan negara berkembang, perkembangan ini diikuti dengan persaingan yang begitu pesat. Dalam menjalankan kegiatan bidang apapun terutama dalam kegiatan ekonomi sebaiknya masyarakat tidak sembarangan dalam bertindak namun harus mengikuti norma yang berlaku. Pemerintah dalam upaya menyetarakan kesejahteraan masyarakatnya membuat wadah perkumpulan masyarakat untuk mengolah dana yang dimiliki atau pinjaman dana untuk membuka suatu usaha. Salah satunya Bank yang bergerak dalam dalam bidang keuangan. Bank perkreditan rakyat merupakan solusi pemerintah memberi kemudahan pada masyarakat tapi dengan syarat dan ketentuan dalam proses peminjaman. Setiap masyarakat yang ingin meminjam uang untuk keperluan tertentu dapat dilakukan di BPR, bagi yang ingin meminjam modal harus memiliki jaminan yang nantinya akan dikalkulasikan sesuai dengan pinjaman yang diinginkan namun tidak jarang staf bank tidak memikirkan jumlah jaminan yang digunakan dengan dana yang dipinjam membuat sering terjadi wanprestasi Penelitian ini menelaah Faktor yang menyebabkan terjadinya wanprestasi dalam perjanjian kredit di PT. Bank Perkreditan Rakyat Hari Depan Denpasar dan menjelaslan upaya PT. Bank Perkreditan Rakyat Hari Depan Denpasar dalam penyelesaian terhadap debitur yang mengalami wanprestasi. Peneliti melakukan pencarian informasi langsung melalui wawancara atau penelitian empiris dengan pendekatan kasus dan Perundangundangan. Selanjutnya data dianalisis menggunakan deskriptif kulitatif. Faktor terjadinya wanprestasi akibat ketelodoran bank dalam mematuhi aturan yang telah digariskan. Upaya yang dilakukan terhadap nasabah yang melakukan wanprestasi yaitu melakukan pembinaan, rescuduling, reconditioning dan retrukturing, apabila tidak terpenuhi akan dilakukan penyelesaian secara dibawah tangan yaitu melakukan penjualan kedua belah pihak , tahap terakhir penetapan eksekusi lewat pengadilan. apabila penetapan sudah dikabulkan, pihak kreditur segera melakukan eksekusi sesuai dengan.
\end{abstract}

Kata Kunci : Kredit, Debitur, Wanprestasi

\begin{abstract}
Indonesia is a developing country, this development is followed by rapid competition. In carrying out activities in any field, especially in economic activities, the community should not act recklessly but must follow the applicable norms. The government in an effort to equalize the welfare of its people creates a forum for community associations to process funds owned or borrowed funds to open a business. One of them is a bank that is engaged in the financial sector. People's credit banks are the government's solution to provide convenience to the community but with terms and conditions in the lending process. Every community who wants to borrow money for certain purposes can be done at BPR, those who want to borrow capital must have collateral which will later be calculated according to the desired loan, but it is not uncommon for bank staff to not think about the amount of collateral used with borrowed funds, resulting in frequent defaults. This study examines the factors that cause default in the credit agreement at PT. The People's Credit Bank for the Future of Denpasar and explained the efforts of PT. The People's Credit Bank of Denpasar is in the process of settling debtors who are in default. Researchers conduct direct information searches through interviews or empirical research with a case and legislation approach. Furthermore, the data were analyzed using qualitative descriptive. The factor for the occurrence of default is due to the negligence of the bank in complying with the rules that have been outlined. Efforts made to customers who are in default are conducting coaching, rescuduling, reconditioning and restructuring, if not fulfilled, a settlement will be carried out under the hands of selling both parties, the last stage is the determination of execution through the court. If the determination has been granted, the creditor immediately carries out the execution in accordance with.
\end{abstract}

Keywords: Credit, Debtor, Default 


\section{PENDAHULUAN}

Dalam perekonomian Indonesia, Negara sebagai wadah dari rakyat untuk meningkatkan kesejahteraan rakyat. Era sekarang uang menjadi yang utama bisa dikatakan dengan uang seseorang dapat memiliki apapun (Sari, 2016). Percaya tidak percaya Indonesia dapat bertahan karena pajak yang dihasilkan dari setiap penghasilan masyarakat serta meningkatkan perekonomian dari masyarakat dan nasional. Semakin padatnya penduduk maka semakin banyak orang yang memerlukan uang demi bertahan hidup (Rochaida, 2016). Bank perkreditan rakyat hari depan Denpasar merupakan solusi bagi masyarakat guna menekan angka kemiskinan namun demi bisa mendapatkan modal usaha harus mengisi formulir serta mengikuti syarat dan ketentuan. Lembaga keuangan merupakan alternatif terbaik saat ini bagi masyarakat yang ingin mengembangkan usaha demi meningkatkan sumber pendapatnya namun demi mendapatkan pinjaman memerlukan beberapa syarat seperti jaminan yang setara dengan modal yang ingin dipinjam serta ketentuan bunga yang berlaku pada setiap koperasi berbeda-beda tergantung besar dana pinjaman. Sasaran bank perkreditan rakyat hari depan Denpasar masyarakat dengan ekonomi menengah kebawah, biasanya jika ada masyarakat ekonomi menengah ke atas akan dipertimbangkan terlebih dahulu baru diputuskan apakah mendapat pinjaman dana atau tidak namun bagi masyarakat ekonomi menengah kebawah akan dipermudah dalam proses peminjaman dana.

Bank perkreditan rakyat hari depan Denpasar dalam memberikan pinjaman harus dilakukan dengan perjanjian kredit yang disepakati oleh peminjam. Dengan adanya perjanjian kredit ini di satu pihak, peminjam memperoleh kredit tersebut dengan harapan agar usaha yang dilakukan dapat berkembang dan dapat memenuhi kebutuhannya yang lain (Oktafiani \& Idris, 2015). Sedangkan pada pihak Bank memperoleh keuntungan dari pemungutan bunga kredit. Disamping itu untuk menjamin pelunasan hutangnya dalam perjanjian kredit tersebut, pihak peminjam diharuskan memberikan jaminan kepada pihak Bank sebagai pelunasan hutang apabila si peminjam suatu saat tidak bias melunasi pinjamannya kepada pihak bank. Jadi sudah seharusnya apabila masing-masing pihak dalam suatu perjanjian yang telah diadakan harus melaksanakan isi perjanjian yang telah disepakati. Setiap pihak yang melakukan perjanjian harus memiliki etikad baik yaitu mematuhi setiap isi perjanjian dan tidak melakukan wanprestasi yang berakibat batalnya suatu perjanjian (Ichsan, 2021).

Para pihak melakukan perjanjian terlebih dahulu mendiskusikan isi perjanjian yang akan ditandatangani dan melaksanakan kewajiban demi mendapatkan hak. Tidak dibenarkan salah satu pihak tidak setuju namun perjanjian tetap dilaksanakan, hal tersebut membuat selisih paham yang berujung terjadi wanprestasi. Bila terjadi ingkar janji maka perjanjian tidak dapat berjalan lagi serta terjadi kemungkinan penuntutan hak oleh pihak yang merasa dirugikan, jika pinjaman atau kredit mengalami kemacetan hingga sampai pihak peminjam tidak memenuhi pelaksanaan perjanjian yaitu pelunasan kredit, maka jaminan si debitur akan ditarik oleh pihak bank sebagai pelunasan utang atau kredit si peminjam (Bandem et al., 2020). Pihak bank dapat mengajukan permohonan pelelangan jaminan tersebut ke Kantor Lelang Negara atau benda yang menjadi jaminan tersebut. dapat dijual bersama-sama oleh pihak Bank dan debitur guna mewujudkan pemenuhan prestasi yang menjadi haknya jika debitur ternyata melakukan wanprestasi. Perwujudan prestasi disini tidak memerlukan perantara hakim karena debitur disini telah menyetujui cara demikian sesuai dengan isi dari perjanjian kredit yang telah disepakati. Pelaksanaan pemenuhan prestasi yang dilakukan sendiri oleh kreditur semacam ini disebut parate eksekusi atau eksekusi langsung. Kendala yang sering terjadi dikala jaminan masyarakat tidak sesuai dengan pinjaman yang diberikan sering kali pihak bank lalai atau tidak memperhitungkan jaminan masyarakat dengan pinjaman yang diberikan membuat bank menjadi rugi.

Permasalahan yang timbul kemudian adalah di satu pihak, apabila setelah melakukan pelelangan atau penjualan benda jaminan milik debitur bersama-sama dengan pihak koperasi ternyata jaminan yang dibayarkan oleh debitur masih bernilai kurang atau jaminan tersebut tidak dapat mencukupi pelunasan utang kreditur kepada pihak bank. Sedangkan di pihak lain, pihak bank harus menuntut pemenuhan prestasi berupa pelunasan utang dari pihak debitur. Terkait dengan masalah tidak mencukupinya hasil eksekusi benda jaminan kredit untuk pelunasan utang debitur kepada pihak bank. Pada setiap perjanjian masing-masing pihak diwajibkan untuk memenuhi apa yang menjadi isi dari perjanjian atau dapat dikatakan bahwa masing-masing pihak wajib untuk memenuhi prestasinya, perjanjian kredit menimbulkan hak dan kewajiban bagi para pihak yang membuat perjanjian kredit.Sehingga dalam pelaksanaannya perjanjian kredit juga dapat menimbulkan akibat hukum bagi 
pihak kreditur dan debitur yang menyepakatinya. Berdasarkan fenomena yang telah dipaparkan, maka penelitian ini mengkaji Faktor yang menyebabkan terjadinya wanprestasi dalam perjanjian kredit di PT. Bank Perkreditan Rakyat Hari Depan Denpasar dan menjelaslan upaya PT. Bank Perkreditan Rakyat Hari Depan Denpasar dalam penyelesaian terhadap debitur yang mengalami wanprestasi.

\section{METODE PENELITIAN}

Penelitian ini didesain dengan penelitian hukum empiris yaitu melakukan pencarian informasi secara langsung ke lapangan yang berfokus pada efektivitas dan dampak terhadap pengawasan Dinas Lingkungan Hidup tentang Bank Perkreditan Rakyat Hari Denpasar dan analisis dalam Informasi yang didapat secara konseptual berkaitan dengan masalah yang sedang diteliti. Penelitian hukum empiris adalah penelitian ke lapangan menggali informasi dengan mengaitkan norma hukum yang terdapat dalam peraturan Perundang-undangan (Waluyo, 1996) \& (Ahmad, 2008). Penyelesaian masalah dalam penelitian ini tidak menyimpang dari hukum positif dan penelitian melalui permasalahan yang dipaparkan di atas. Pendekatan yang digunakan adalah pendekatann lapangan guna mendapatkan informasi dengan berpatokan pada Undang-undang. Pendekatan kasus dilakukan guna melihat, mencatat dan memahami permasalahan yang diangkat dalam skripsi ini dengan tidak keluar dari zona hukum positif. Setelah data penelitian terkumpul selanjutnya dianalisis dalam bentuk deskriptif kualitatif.

\section{HASIL DAN PEMBAHASAN}

\section{Faktor yang Menyebabkan Terjadinya Wanprestasi dalam Perjanjian Kredit di PT. Bank Perkreditan Rakyat Hari Depan Denpasar}

Sudah diketahui banyak orang bila seseorang ingin meminjam modal usaha harus ada jaminan yang harga jualnya sesuai modal yang dipinjam, kegiatan ini dilakukan oleh lembaga-lembaga keuangan kepada nasabah atau anggota mereka golongan ekonomi menengah kebawah. Tidak semudah yang terlihat sebelum melakukan pinjaman harus mengisi formulir serta mengajak salah satu sanak saudara sebagai saksi telah dilakukannya perjanjian pinjam dana antara nasabah dengan pihak lembaga keuangan. Bank perkreditan rakyat hari depan Denpasar dalam melakukan suatu perjanjian para pihak harus sepakat mengenai isi perjanjian, para pihak yang bersangkutan secara bersama-sama terlebih dahulu mendiskusikan isi perjanjian agar tidak ada pihak tidak menyukai perjanjian. Tujuan perjanjian sendiri mempermudah para pihak untuk saling mendapatkan hak tanpa melupakan kewajiban, hal itu selalu ada di perjanjian. Terjadinya wanprestasi dan kemacetan kredit dari nasabah terjadi Keteledoran bank mematuhi peraturan pemberian kredit yang telah digariskan; Terlalu mudah memberikan kredit, yang disebabkan karena tidak ada patokan yang jelas tentang standar kelayakan permintaan kredit yang diajukan; Konsentrasi dana kredit pada sekelompok debitur atau sektor usaha yang beresiko tinggi; Kurang memadainya jumlah eksekutif dan staf bagian kredit yang berpengalaman; Lemahnya bimbingan dan pengawasan pimpinan kepada para eksekutif dan staf bagian kredit; Jumlah pemberian kredit yang melampaui batas kemampuan bank; Lemahnya kemampuan bank mendeteksi kemungkinan timbulnya kredit bermasalah, termasuk mendeteksi arah perkembangan arus kas.

Para pihak harus memahami dasar perjanjian seperti arti kata sepakat, kewajiban dulu lalu mendapatkan hak, sanksi bagi pihak yang terbukti melakukan wanprestasi serta harus berisi kuasa hukum, nantinya kuasa hukum yang mengarahkan para pihak menyelesaikan perkara akibat wanprestasi salah satu pihak (Satrio, 1995). Isi perjanjian kredit tersebut dari pihak debitur sudah harus mengerti akan isi perjanjian kredit tersebut, karena dalam perjanjian tersebut, debitur yang tidak melunasi hutangnya sudah menyadari bahwa barang berharganya, baik barang yang bergerak maupun yang tidak bergerak, baik yang sudah ada maupun yang akan ada dikemudian hari, akan menjadi jaminan dan bank akan menyita benda atau harta kekayaan milik debitur tersebut untuk menutupi kekurangan pelunasan utang debitur. Sesuai perjanjian kredit tersebut, maka pihak bank dapat menyita benda-benda atau harta kekayaan milik debitur melalui penetapan pengadilan. Kemudian diajukan permohonan kepada kantor Lelang Negara untuk mengambil harta kekayaan debitur yang lain untuk melunasi hutang-hutang debitur. 


\section{Upaya PT. Bank Perkreditan Rakyat Hari Depan Denpasar dalam Penyelesaian terhadap Debitur yang Mengalami Wanprestasi.}

Sebuah perjanjian yang memasukan kuasa hukum untuk mengamankan aset masing-masing jika suatu hari terjadi wanprestasi tugas kuasa hukum memberi pilihan penyelesaian sengketa mulai dari memakan waktu dan tenaga yang banyak sampai penyelesaian alternatif atau yang lagi booming belakangan tahun ini (Bandem et al., 2020). Dua cara penyelesaian sengketa yaitu litigasi dan non litigasi, keduanya memiliki aturan ketentuan berbeda. Mulai dari jalur litigasi, setiap pihak merasa dirugikan mengajukan gugatan melalui pengadilan, mempercayakan putusan dan aturan main oleh hakim ketua. Biasanya setiap orang yang melakukan litigasi sudah tidak menemukan titik terang dari negosiasi dari penyelesaian secara non litigasi. Aturan waktu serta pemanggilan beberapa orang yang menjadi saksi membuat proses litigasi berjalan lambat, butuh waktu beberapa bulan menyelesaikan tuntutan yang diajukan. Memilih jalur non litigasi atau jalur singkat penyelesaian masalah sangat tepat karena proses tidak membutuhkan waktu lama seperti jalur litigasi (Hermansyah, 2014). Cara penyelesaiannya cukup mudah yaitu kedua belah pihak melakukan negosiasi atau mencari jalan tengah agar perjanjian kembali berlanjut dan selesai sesuai isi perjanjian yang sudah disepakati bersama. Secara meluas penyelesaian sengketa non litigasi dapat dilakukan efisien waktu dan dana tidak begitu besar yaitu:

1. Penjadwalan kembali (rescheduling), yaitu perubahan syarat kredit yang menyangkut jadwal pembayaran atau jangka waktunya, termasuk masa tenggang, baik yang meliputi perubahan besarnya atau tidaknya angsuran. Tujuannya untuk debitur dapat menyusun dana langsung "cash flow" secara lebih pasti, memastikan pembayaran yang lebih tepat, memungkinkan debitur untuk mengatur pembayaran kepada pihak lain.

2. Persyaratan kembali (reconditioning), yaitu perubahan sebagai atau seluruh sayarat - syarat kredit yang tidak terbatas pada perubahan jadwal pembayaran, jangka waktu dana atau persyaratan lainnya sepanjang tidak menyangkut perubahan maksimal saldo kredit. Upaya ini bertujuan untuk menyempurnakan legal documentation, menyesuaikan kemampuan membayar debitur dengan kondisi yang terjangkau oleh debitur (angsuran pokok, denda, penalti dan biayabiaya lainnya).

3. Penataan kembali (restructuring), yaitu perubahan syarat-syarat kredit yang menyangkut penambahan dana, konversi seluruh atau sebagai tunggakan bunga menjadi pokok kredit baru. Tujuan dari dilakukannya penataan kembali untuk memberikan kesempatan pada debitur untuk berusaha kembali melalui penambahan dana, memperbaiki kolektibilitas pinjaman debitur melalui tunggakan bunga, denda, penalti, dan biaya-biaya lainnya.

Penyelesaian sengketa melalui alternative dispute resolution atau disebut non litigasi adalah penyelesaian sengketa diluar pengadilan berdasarkan kesepakatan para pihak dengan mengesampingkan penyelesaian sengketa melalui proses pengadilan (litigasi) (Siska et al., 2019). Setiap permasalah pasti ada jalan tengah demi kebaikan kedua pihak, kebanyakan pihak yang mengambil jalur non litigasi permasalahannya selesai dengan waktu singkat namun tidak semua penyelesaian secara non litigasi menemukan titik tengah. Perselisihan antara pihak yang bersitegang bahwasanya pihaknya benar membuat non litigasi tidak dapat dilakukan maka beralih ke jalur litigasi. (Fuady, 2007). Persetujuan hakim diperlukan sebelum memulai sidang perkara wanprestasi, menunggu selama seminggu minimal dilanjutkan pemanggilan pihak-pihak terkait dalam perjanjian seperti para pihak, saksi, pegawai koperasi yang menyaksikan perjanjian dibuat. Akhir sidang memutus salah satu pihak keluar sebagai pemenang, jika pihak nasabah menang akan mendapatkan ganti rugi dari pihak koperasi, jika pihak koperasi menang dalam persidangan maka berhak melelang jaminan milik nasabah sesuai isi perjanjian serta berhak meminta ganti rugi apabila hasil jual barang jaminan nasabah tidak mencukupi hutang nasabah.

Terjadinya kesalahan dalam memberikan pinjaman namun tidak memperhitungkan nilai tukar suatu jaminan membuat bank menjadi rugi dan susah menuntut pihak debitur karena kesalahan fatal ada pada bank bukan berarti pihak debitur bisa lepas begitu saja sebagai masyarakat yang taat aturan pihak debitur juga wajib melunasi sisa pembayaran atau wanprestasi dari perjanjian yang disepakati antara pihak bank dan pihak debitur yang bersifat mengikat bagi kedua pihak yang bersangkutan. Tidak terjalin komunikasi yang baik antar pihak bank baik antara atasan dengan staf atau sebaliknya terkait jaminan pinjaman yang diajukan masyarakat terjadinya penurunan nilai saham yang dimiliki bank, bagaimana tidak seseorang dapat dengan gampang meminjam modal untuk urusan tertentu 
dengan jumlah berapapun namun jaminan yang digunakan tidak memiliki nilai sama dengan dana yang dipinjam.

Pemerintah sebagai pengamat keuangan negara memberitahukan kepada pihak bank secara berulang-ulang agar teliti dalam melakukan transaksi terutama dalam bidang keuangan karena sedikit melakukan kesalahan akan berpengaruh besar kepada perusahaan begitu sebaliknya semakin efisien dalam melakukan suatu pekerjaan hasil yang diperoleh akan dinikmati seluruh penghuni perusahaan tanpa kecuali. PT. Bank perkreditan rakyat hari depan Denpasar menjadi contoh kesalah kecil yang dibuat tanpa disadari secara terus menerus melakukan pemberian pinjaman tanpa memikirkan nilai dari suatu jaminan yang digunakan debitur membuat kewalahan pihak bank dalam upaya mengembalikan dana yang dipinjam debitur tanpa terjadi kerugian dari pihak bank sendiri.

\section{SIMPULAN DAN SARAN}

\section{Simpulan}

Berdasarkan hasil analisis data, dapat disimpulkan bahwa Faktor yang menyebabkan terjadinya wanprestasi karena Keteledoran bank mematuhi peraturan pemberian kredit yang telah digariskan, Terlalu mudah memberikan kredit, yang disebabkan karena tidak ada patokan yang jelas tentang standar kelayakan permintaan kredit yang diajukan, Konsentrasi dana kredit pada sekelompok debitur atau sektor usaha yang beresiko tinggi, Kurang memadainya jumlah eksekutif dan staf bagian kredit yang berpengalaman; Lemahnya bimbingan dan pengawasan pimpinan kepada para eksekutif dan staf bagian kredit, jumlah pemberian kredit yang melampaui batas kemampuan bank, Lemahnya kemampuan bank mendeteksi kemungkinan timbulnya kredit bermasalah, termasuk mendeteksi arah perkembangan arus kas (cash flow) debitur lama. Upaya PT. Bank perkreditan rakyat hari depan Denpasar dalam penyelesaian terhadap debitur yang mengalami wanprestasi, bahwa sebelum melakukan upaya hukum, bank melakukan pembinaan terlebih dahulu dengan melakukan rescuduling, reconditioning dan retrukturing, apabila tidak terpenuhi akan dilakukan penyelesaian secara dibawah tangan yaitu melakukan penjualan kedua belah pihak dan apabila tidak dapat diselesaikan, maka dilakukan melakukan tindakan hukum dengan mengajukan permohonan penetapan eksekusi lewat pengadilan, apabila penetapan sudah dikabulkan, pihak kreditur segera melakukan eksekusi sesuai dengan tanggal dan hari yang telah ditetapkan dalam penetapan eksekusi, dalam pelaksanaan eksekusi dihadiri oleh pihak pengadilan dan apabila perlu dibantu oleh pihak kepolisian.

\section{Saran}

Berkaitan dengan simpulan penelitian di atas, adapun saran yang diberikan yaitu lembaga perbankan diharapkan untuk lebih berhati-hati dalam mengeluarkan kredit kepada calon debitur, karena dalam praktek perbankan di Kabupaten Tabanan para calon debitur tidak mengetahui sepenuhnya isi dari perjanjian, karena dalam penandatanganan akad kredit pihak bank menyodorkan blangko yang kosong, maka untuk menghindari terjadinya debitur wanprestasi kredit yang dikeluarkan disesuaikan dengan kebutuhan dan kemampuan debitur. Peranan petugas bank dalam memberikan penjelasan kepada calon debitur hendaknya di dalam penandatanganan akad kredit dilengkapi terlebih dahulu supaya mudah dimengerti oleh debitur tentang apa yang merupakan hak dan kewajiban. Memberikan penjelasan yang jelas kepada calon debitur karena tidak semua pemikiran dan golongan calon debitur sama ditambah usia dari setiap calon debitur bervariasi mengharuskan setiap petugas bank memberikan penjabaran sesuai dengan daya tangkap calon debitur agar tidak terjadi kesalahan dalam komunikasi.

\section{DAFTAR PUSTAKA}

Ahmad, B. (2008). Metode Penelitian Hukum. Pustakasetia.

Bandem, I. W., Wisadnya, I. W., \& Mordan, T. (2020). Akibat Hukum Perbuatan Wanprestasi dalam

Perjanjian Hutang-Piutang. Raad Kertha, 03(01), 1-21.

Fuady, M. (2007). Hukum Kontrak dari Sudut pandang Hukum Bisnis. Bandung. Citra Aditya Bakti. Hermansyah. (2014). Kepastian Hukum dalam Penyelesaian Kredit Bermasalah. Kencana.

Ichsan, A. (2021). Hukum Perdata. Jakarta. Pembimbing Masa.

Oktafiani, L., \& Idris, I. (2015). Pelaksanaan Pemberian Kredit dengan Jaminan Hak Tanggungan

Pada Debitur PT. Bank DKI Jakarta Pusat. Lex Jurnalica, 12(2), 79-90.

Rochaida, E. (2016). Dampak Pertumbuhan Penduduk Terhadap Pertumbuhan. Forum Ekonomi, 
$18(1), 14-24$.

Sari, S. W. (2016). Perkembangan dan Pemikiran Uang dari Masa ke Masa. Jurnal Ekonomi Syariah, $3(1), 39-58$.

Satrio. (1995). Perikatan yang Lahir dari Perjanjian. Citra Aditya Bakti.

Siska, S. N. L. P., Putra, A. I. B., \& Wiratni, D. A. . S. (2019). Perlindungan Hukum terhadap Pelaku Usaha Online Shop Apabila Terjadi Wanprestasi Yang Dilakukan oleh Pemberi Jasa Endorse di Kota Denpasar. Journal Ilmu Hukum, 7(4), 1-19.

Waluyo, B. (1996). Penelitian Hukum Praktek. Sinar Grafika. 